\title{
Aspects of life history patterns of the cichlid fish Hemichromis fasciatus Peters, 1857 from Okpara Stream, Northern Benin, West Africa
}

\author{
Rachad Sidi Imorou ${ }^{\circledR}$, Alphonse Adite ${ }^{\circledR}$, Hamidou Arame ${ }^{\circledR}$, Pejanos Stanislas Sonon ${ }^{\circledR}$ \\ Cite this article as: \\ Sidi Imorou, R., Adite, A., Arame, H., Sonon, P.S. (2020). Aspects of life history patterns of the cichlid fish Hemichromis fasciatus Peters, 1857 from \\ Okpara Stream, Northern Benin, West Africa. Aquatic Research, 3(2), 110-123. https://doi.org/10.3153/AR20010
}

University of Abomey-Calavi, Faculty of Sciences and Technics, Department of Zoology, Loboratory of Ecology and Aquatic Ecosystems Management, BP: 526, Cotonou, Benin

ORCID IDs of the author(s): R.S.I. 0000-0001-6910-0059 A.A. $0000-0002-2255-4464$ H.A. 0000-0002-0039-7787 P.S.S. 0000-0003-3810-7623

Submitted: 28.12 .2019

Revision requested: 08.02 .2020

Last revision received: 12.02 .2020

Accepted: 18.02.2020

Published online: 22.03 .2020

\begin{abstract}
The piscivorous cichlid Hemichromis fasciatus dominated the Okpara Stream of Oueme River in Benin, and numerically made $29.49 \%$ of the fish community. Some aspects of the reproductive biology of this fresh/ brackish water cichlid were examined to evaluate the spawning patterns and establishment of the species in Okpara Stream. Hemichromis fasciatus individuals were sampled monthly during 18 months from December 2015 to May 2017 with seine, cast nets, gillnets, hooks and traps. Among the 2,818 individuals sampled, 55.43\% were females and $37.33 \%$ were males with a sex-ratio of 1.49:1. The species showed low fecundities ranging between 113 and 1,716 oocytes. Length at first sexual maturity $\left(\mathrm{L}_{50}\right)$ in Okpara Stream were reduced, $9.22 \mathrm{~cm}$-TL (females) and $10.95 \mathrm{~cm}$-TL (males), indicating an early maturation. The ovarian structure give evidence of multiple spawning and the species reproduces all seasons. In Okpara Stream, Hemichromis fasciatus exhibited a life history strategy between " $r$ " and " $K$ " selection, yet, close to " $r$ " selection. Because the length at first capture $\left(\mathrm{Lc}_{50}=8.78 \mathrm{~cm}\right)$ is lower than sizes at first sexual maturity, stocks of spawners could be reduced and leading to low recruitment.
\end{abstract}

Keywords: Life-history, Hemichromis fasciatus, Okpara Stream, Multiple spawning, Recruitment, Early maturity

Correspondence:

Alphonse ADITE

E-mail: alphonseadite $@$ gmail.com

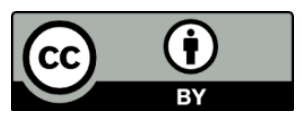

CCopyright 2020 by ScientificWebJournals Available online at

http://aquatres.scientificwebjournals.com 


\section{Introduction}

Hemichromis fasciatus (Actinopterygii: Perciformes: Cichlidae) is a widespread African piscivorous cichlid dwelling most inland waters such as freshwater lakes, brackish waters, estuaries, rivers, streams floodplains etc. because of its high tolerance to environmental conditions (Leveque and Paugy, 2006, Kuela 2002, Paugy et al., 2003, Kantoussan 2007, Montchowui et al., 2007 Sidi Imorou et al., 2019a). Like most African cichlids and despite its reduced abundance, the species showed great fisheries importance in the most water bodies. As colourful species, Hemichromis fasciatus is utilized as ornamental fish and raised in the aquarium. The species has a laterally cylindrical compressed body mainly covered with cycloid scales ranging from 28 to 30 scales in lateral line (Lévêque and Paugy, 2006). Juveniles lack the orange-red coloring of adults and show traces of intervening dark stripes. Subadult and adults in a state of stress also show dark interstices. The maximum size observed is $204 \mathrm{~mm}$ standard length (SL) (Lévêque and Paugy, 2006).

As feeding habit, $H$. fasciatus showed a moderate diet breadth and foraged mainly on fishes, aquatic insects, zooplankton and detritus. Unlike other cichlids, H. fasciatus is monogamous and protects eggs and fry but does not incubate orally (Albaret, 1982). The eggs are laid on a block of rock, and are fixed on a submerged support, in a clean place, sheltered from the current and at a depth of 10 to $20 \mathrm{~cm}$ (Daget, 1956). Parental custody is highly developed in this species; both parents protect and accompany their offspring until they reach a size of 2 to $3 \mathrm{~cm}$.

In Benin, $H$. fasciatus is common and was recorded in almost all water bodies and running waters where this piscivorous cichlid showed reduced abundances varying between $0.37 \%$ and $6 \%$ of the fish community, but constituted an important fisheries resource (Jackson et al., 2013; Montchowui et al., 2007). However, recent fisheries survey by Sidi Imorou et al. (2019a) in the Okpara stream (North Benin), a tributary of the Oueme River indicated that $H$. fasciatus dominated this stream making numerically $29.49 \%$ of the fish assemblages. Consequently, in the Okpara Stream, the species is intensively exploited and thus, displayed high commercial and economic values in this northern running water.

Despite its high abundance and fisheries importance in the Okpara stream associated with ongoing environmental threats, nothing is known about the life history strategy and the reproductive ecology of this piscivorous species in this riverine water. This documentation is badly needed to characterize the species and to set up conservation, valorization and a rational exploitation scheme that assure the ecosystem balance.
The purpose of this fisheries study is to document some aspects of the reproductive biology of Hemichromis fasciatus from Okpara Stream in order to provide basic knowledge needed for management studies.

\section{Material and Methods}

\section{Study Area and Sampling Sites}

The study was performed in Okpara stream $(200 \mathrm{Km})$, one of the longest tributary of the Oueme River $(510 \mathrm{Km})$. This river sourced in the Northeast of Benin country at $450 \mathrm{~m}$ of altitude. Oueme River is the longest river and the more important in term of fish species richness and fish production (Lalèyè $e t$ al., 2004). Okpara stream is stretched between $8^{\circ} 14^{\prime}$ $9^{\circ} 45^{\prime}$ North and $2^{\circ} 35^{\prime}-3^{\circ} 25^{\prime}$ East and belongs to the northern hydrographic network. The Benin northern region, is characterized by a tropical climate with an alternation of dry season (November - April) and wet season (May - August) with a flood period from September to October. Annual ambient temperature averaged $26.6^{\circ} \mathrm{C}$ and lower temperatures $\left(18^{\circ} \mathrm{C}\right)$ were recorded in December-January. Annual mean rainfall is about $1200 \mathrm{~mm}$ with a peak $(2100 \mathrm{~mm})$ recorded in July or August (Kora, 2006). Soils are ferruginous and alluvial and covered by a wooded savanna of Parkia biglobosa, Khaya senegalensis, Vitellaria paradoxa, marshy meadows, bamboo and fallow bushes (Dossou-Yovo, 2009). Commercial fisheries take place in Okpara Stream that was exploited by the surrounding populations. Also, this stream supplies the surrounding populations with drinking water from a dam built by SONEB, the Benin water company. Furthermore, Okpara Stream provides water for irrigated agriculture.

For this study, $H$. fasciatus individuals were collected in five (05) sampling sites (Figure 1). These sites were chosen according to localities, accessibility, fisheries importance and levels of sites degradation. Site 1 is situated in Perere Township at Okpara up stream and Site 2 is localized in Parakou Township at Gadela village (Okpara up stream), at about 2 $\mathrm{km}$ from SONEB dam. Site 3 is located at Kpassa village where a dam was built to serve as a source of drinking water for the populations of Tchaourou and Parakou Townships and surrounding villages. Site 4 is situated around Okpara downstream at Yarimarou village (Tchaourou Township) where the dam withdraws its water. Site 5 is also located around Okpara downstream at Sui village (Tchaourou Township). At the five collecting sites, samplings were done in the "aquatic vegetation habitat" at the edge of the stream and in the "open water habitat" exempt of vegetation, but characterized by a relatively high depth (Sidi Imorou et al., 2019a). 


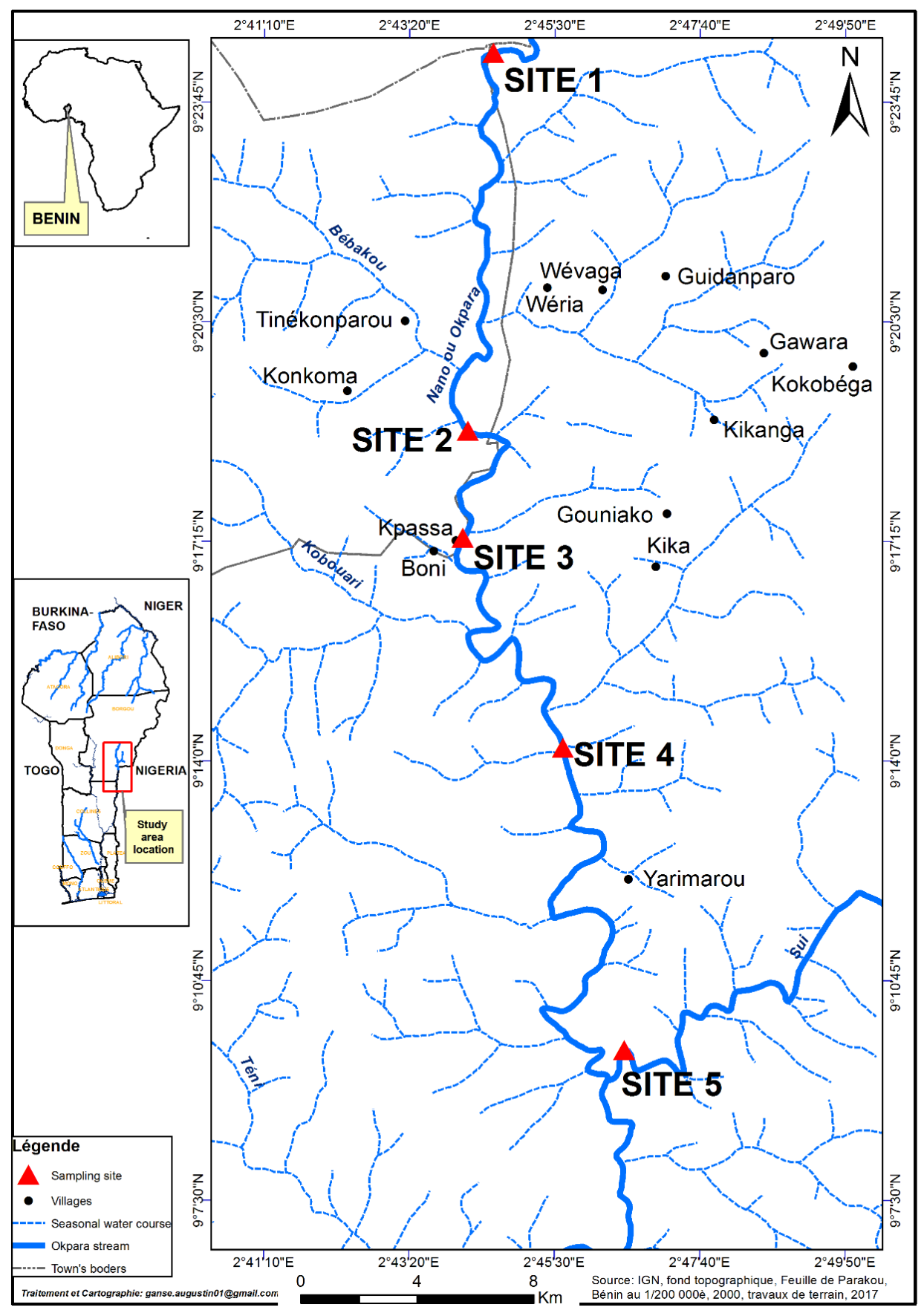

Figure 1. Okpara stream and sampling sites. Site $1=$ Perere Township, Site $2=$ Gadela village (Parakou Township), Site $3=$ Kpassa village (Tchaourou Township), Site 4= Yarimarou village (Tchaourou Township), Site $5=$ Sui village (Tchaourou Township).

Okpara Stream displayed a relatively adequate water quality with moderate temperatures ranging between 25 to $30.1{ }^{\circ} \mathrm{C}$, depths between 17 to $1080 \mathrm{~cm}$ and low transparencies varying between 10 and $78.1 \mathrm{~cm}$. Dissolved oxygen concentrations ranged between 0.44 and $5.66 \mathrm{mg} / \mathrm{l}$ and the percentages of saturation were moderate to low and varied from 6.37 to
$75.3 \%$. The water was acid or alkaline with $\mathrm{pHs}$ ranging between 6.4 to 8.1 (Sidi Imorou et al., 2019a). As results, and based on the physicochemical features recorded, the Okpara stream is relatively suitable for a high primary production and the prominence of the fish fauna. 


\section{Fish Sampling}

Hemichromis fasciatus samplings were done once a month from December 2015 to May 2017 at all sites. Collections were done in open water with experimental gill net and in aquatic vegetation and with seines (Winemiller, 1992; Adite et al., 2013; Gbaguidi and Adite, 2016, Sidi Imorou et al., 2019a). Also, fish samplings were directly made in fishermen artisanal captures with gill net $(50 \mathrm{~m} \times 1.30 \mathrm{~m}, 2.5 \mathrm{~mm}$-mesh; $50 \mathrm{~m} \times 1.30 \mathrm{~m}, 30 \mathrm{~mm}$-mesh; $50 \mathrm{~m} \times 1.30 \mathrm{~m}, 35 \mathrm{~mm}$-mesh). Fish species were identified using references such as Lévêque and Paugy (2006). After collection, fishes were preserved in $10 \%$ formalin and then transported to the Laboratory of Ecology and Management of Aquatic Ecosystem (LEMEA) where they were kept in 70\% ethanol to make easier biological observations (Murphy and Willis, 1996).

\section{Laboratory Procedure}

In the laboratory, fishes were removed from the ethanol and measured for total length (TL) and standard length (SL) to a nearest $0.1 \mathrm{~mm}$ with a digital caliper, and then weighed to the nearest $0.1 \mathrm{~g}$ with an electronic scale. Before dissection, sexes were identified by examination of anal and genital opening (Gbaguidi and Adite, 2016): males possess a tinny sexual opening that also serves as anal orifice whereas females possess two (2) distinct orifices. After dissection, gonad weight, gonad length and width were recorded, and stage of maturity (I, II, III, IV, or V) in both males and females were evaluated using the gonad maturation scale described by King (1995) : (1) stage "immature" testis are simple translucent filaments and ovaries are not developed, they are small and translucent. Oocytes are not visible to the naked eye; (2) stage "Beginning of maturation" During development, testicles are yellow or ocher color and ovaries are opaque orange with opaque oocytes and visible to the naked eye; (3) "Advanced maturity" testis are large and opaque white, ovaries are mature and fills the ventral region of the abdominal cavity with translucent eggs large and round; (4) stage "Mature" corresponding to Ripe testis, fully developed and white milt was expelled by gentle pressure on the abdomen. For females, Ovaries are mature and oocytes are ready to be expelled; (5) expelled sperm, soft testes without milt, and expelled oocytes, narrowing of the ovaries with some residual eggs.

The ovaries and testicles are then preserved in 90\% alcohol. Oocytes from mature ovaries were then separated using forceps and then enumerated. Oocytes diameters were recorded using a binocular loupe. Batch fecundity was estimated as the total number of oocytes in a ripe ovary. $H$. fasciatus oocytes showed an ovoid form comprising with two dimensions $\left(\mathrm{d}_{1}\right.$ and $\mathrm{d}_{2}$ ), measured with a calibrated eyepiece micrometer mounted to a dissecting stereomicroscope. Therefore, the theoretical diameters (d) utilized to construct the frequency histograms of egg diameters were the geometric means (d) of $d_{1}$ and $\mathrm{d}_{2}$, expressed as following:

$d=\sqrt{(\mathrm{d} 1 \times \mathrm{d} 2)}$ (Adite et al., 2017)

\section{Data Analysis}

Data collected was recorded in Excel spreadsheet and analyzed with SPSS software version 21.0. The length of the smallest mature specimen was the basis of the categorization of the different life stages (Juveniles, subadults and adults) and the length at first sexual maturation $\left(\mathrm{TL}_{50}\right)$ for $\mathrm{H}$. fasciatus (male and female) was estimated as the length at which $50 \%$ of the individual were mature as predicted by the formula of Ghorbel et al. (1996):

$P=\frac{1}{1+e^{-(a+b T L)}}$,

Where $\mathrm{P}$ is the pourcentage of individual mature, TL the total length, $\mathrm{a}$ and $\mathrm{b}$ are constants. The length at first sexual maturation were determined by: $T L_{50}=\frac{-a}{b}$

The sex ratio was computed as the ratio between the number of males and the number of females. In order to evaluate the spawning periodicity, the gonadosomatic indexes (GSI) were calculated on the monthly basis for males and females following the formula:

\section{GSI $=(\operatorname{gonad}$ weight $/$ body weight $) * 100$.}

The batch fecundity was estimated for ripe ovaries, and the relationship between fecundity (F) and Total length (TL) was determinate following the curvilinear formula:

$\mathbf{F}=\mathbf{a} \mathbf{T L}^{\mathbf{b}}$, where $\mathrm{a}$ and $\mathrm{b}$ are the parameters of the regression

In addition, the linear relationship between fecundity $(F)$ and body weight $(\mathrm{W})$ was examined following linear regression:

$\mathbf{F}=\mathbf{b W}+\mathbf{a}$, with $a$ is the intercept, and $b$ the slope.

For each season (flood, dry, wet), a mature gonad with a highest GSI was randomly chosen and frequency distributions of oocyte diameters were plotted to examine the trends of egg maturations and weather or not there was production of multiple cohorts per spawning season. The mean values of oocyte diameters and gonadosommatic index (IGS) were given with their standard deviation (mean \pm standard deviation). Gender percentages (sex ratio) and length at first sexual maturity were compared using the $\chi^{2}$ test. Multiple comparisons of IGS averages, and oocyte diameter were performed using a oneway ANOVA based on sex and seasons. The differences are considered significant at $\mathrm{p}<0.05$. All analyze were done by SPSS Software version 21. 


\section{Results and Discussion}

\section{Population Structure and Sex Ratio}

In Okpara Stream, a total of 2,818 individuals of Hemichromis fasciatus were sampled from December 2015 to May 2017. This abundance represented $29.49 \%$ of the fish assemblages making this piscivorous cichlid, the dominant species of Okpara Stream fish community. In this stream, $H$. fasciatus exhibited a bimodal size distributions dominated by individuals of total length ranging between $9-11 \mathrm{~cm}$ (Figure 2). Larger size $(>11 \mathrm{~cm})$ abundances were reduced.

Of the 2,818 H. fasciatus specimen, 55.43\% (1562 individuals) were females, $37.33 \%$ (1052 individuals) were males and $7.24 \%$ (204 individuals) were unidentified. This corresponded to a sex-ratio of 1:1.49 that is in favor of females. This sex-ratio is significantly different to the theoretical sex ratio, $1: 1\left(\chi^{2}=99.503 p<0.05\right)$ (Table 1$)$. Also, the sex ratio varied significantly with seasons with females dominating the dry, wet and flood fish assemblages (Table 2).

\section{Evolution of Gonadosomatic Index (GSI) and Spawning Time}

Figure 3 showed the variation of the gonadosomatic index of $H$. fasciatus during the sampling period. Overall, the GSI ranged from 0.001 to 15.202 and averaged $3.186 \pm 2.64$ for the females and there were significant difference $\left(\mathrm{F}_{18,1544}=\right.$ $2.588 ; \mathrm{p}<0.05)$ monthly variations. In males, the GSI values were reduced and ranged between 0.01 and 1.70 , with a mean of $0.6 \pm 0.007$. Like the females, the GSI of males showed significant $\left(\mathrm{F}_{18,1052}=8.144 ; \mathrm{p}<0.05\right)$ monthly variations.

Mature individuals (Stage 2, 3 and 4) are present all months round with the highest proportions obtained in April (78.88\%), May (84.54\%), June (82.29\%), July (80.32\%) in males (Figure 4) and May (98.39\%), June (91.56\%), July (77.52\%) and August (75.00\%) among females (Figure 5). According to seasons, the wet and the flood were most favorable for the maturation of fishes with $96.52 \%$ and $95.82 \%$ respectively mature individuals.

\section{Size at Sexual Maturity}

Individuals of $H$. fasciatus with gonads at stages 2,3 and 4 of the maturation scales were considered as mature and used to estimate the size at maturation (SSM). For the male, the smallest mature individual measured $8 \mathrm{~cm}$-TL and weighted $8.2 \mathrm{~g}$, and the smallest mature individual for females measured $6.4 \mathrm{~cm}$-TL and weighted $4.68 \mathrm{~g}$. Percentage of ripe gonads reached $100 \%$ at sizes $14-17 \mathrm{~cm}$ for females and $15-17$ $\mathrm{cm}$ for males. Figures 6 and 7 illustrated the sigmoid curves generated by the plot of ripe gonad percentages against total length, respectively for males and females. The sigmoid model showed that the sizes at sexual maturity for male and female were $10.98 \mathrm{~cm}$-TL and $9.22 \mathrm{~cm}-\mathrm{LT}$, respectively. The sizes at maturity are not significantly different $\left(\chi^{2}=0.048475\right.$, $p>0.05)$ between males and females. The regression's equations were:

$$
\begin{aligned}
& P_{f}=\frac{1}{1+e^{-(-4.9345+0.5351 T L)}} ; \mathrm{r}=0.95 \text { (for females) } \\
& P_{m}=\frac{1}{\left.1+e^{-(-6.1074+0.5558 T L}\right)} ; \mathrm{r}=0.91 \text { (for males) }
\end{aligned}
$$

\section{Ovarian Structure and Oocyte Sizes}

Like in most cichlids, Hemichromis fasciatus possesses a pair gonads (Moyle, 1988; Gbaguidi and Adite, 2016). Eggs showed an ovoid shape and diameters varied from $0.800 \mathrm{~mm}$ to $1.5297 \mathrm{~mm}$ with a mean of $1.10 \pm 0.11 \mathrm{~mm}$. Overall, the oocytes exhibited seasonal variations of diameters that ranged between $0.8944-1.5297$ (mean= $1.1280 \pm 0.1), 0.949-1.510$ $($ mean $=1.192 \pm 0.12)$ and $0.80-1.342($ mean $=0.983 \pm 0.08)$ during wet, flood and dry. Egg diameter frequency distributions by seasons showed unimodal distributions (Figure 8).

\section{Absolute and Relative Fecundity}

Of the 2,818 individuals of $H$. fasciatus sampled, 821 mature females were recorded and were used to estimate batch fecundities. In this study, $H$. fasciatus showed batch fecundity ranging between 113 oocytes for an individual of $\mathrm{TL}=8.9$ $\mathrm{cm}(\mathrm{W}=14.4 \mathrm{~g}, \mathrm{GSI}=2.08)$ to 1716 oocytes for an individual of $\mathrm{TL}=9.7 \mathrm{~cm}(\mathrm{~W}=19.5 \mathrm{~g}, \mathrm{GSI}=5.64)$ with an average value of $857 \pm 284.78$ oocytes for the fish assemblages. Relative fecundity varied from 15.21 oocytes/g $(15<\mathrm{TL}<17)$ to 71.015 oocytes/g $(7<\mathrm{TL}<9)$ (Table 2$)$. Power curve fitted to total length (TL) and fecundity (F) scatter plot showed that batch fecundity significantly increase with TL $(r=0.93$, $\mathrm{p}<0.05$ ) (Figure 8). Also linear regression fitted to body weight (W) and batch fecundity scatter plot showed that fecundity significantly $(\mathrm{r}=0.89, \mathrm{p}<0.05)$ increase with body weight (Figure 9). Regressions equations were as follows:

$$
\begin{aligned}
& F=16.369 \mathrm{TL}^{1.8637}(\mathrm{r}=\mathbf{0 . 9 3}, \mathrm{N}=\mathbf{8 2 1})(\text { Figure } 9) \text { and } \\
& \mathrm{F}=\mathbf{2 2 . 0 1 7} \mathrm{W}+\mathbf{7 1 5 . 8 7}(\mathrm{r}=\mathbf{0 . 8 9}, \mathrm{N}=\mathbf{8 2 1})(\text { Figure } 10)
\end{aligned}
$$

With: F= Fecundity (Number of oocytes); TL= Total length $(\mathrm{cm}) ; \mathrm{W}=$ Body weight $(\mathrm{g}) ; \mathrm{N}=$ Number of mature females; $\mathrm{r}=$ correlation coefficient 
Table 1. Seasonal variations of the sex-ratio of $H$. fasciatus collected from December 2015 to May 2017 in Okpara Stream (North Benin)

\begin{tabular}{lllll}
\hline Seasons & Males & Females & Sex ratio (M:F) & $\chi^{2}$ \\
\hline Dry & 590 & 693 & $1: 1.18$ & $\chi^{2}=8.2689, \mathrm{p}<0.05$ \\
Wet & 422 & 766 & $1: 1.82$ & $\chi^{2}=99.609, \mathrm{p}<0.05$ \\
Flood & 40 & 103 & $1: 2.58$ & $\chi^{2}=27.755, \mathrm{p}<0.05$ \\
Total & 1052 & 1562 & $1: 1.49$ & $\chi^{2}=99.503, \mathrm{p}<0.05$ \\
\hline
\end{tabular}

Table 2. Mean, range and relative fecundities by length classes of $H$. fasciatus collected from Okpara Stream (North Benin)

\begin{tabular}{lllllllll}
\hline $\begin{array}{l}\text { TL class } \\
\text { (cm) }\end{array}$ & N & $\begin{array}{l}\text { Mean body } \\
\text { weigth }(\mathbf{g})\end{array}$ & $\begin{array}{l}\text { Mean ovary } \\
\text { weigth }(\mathbf{g})\end{array}$ & $\begin{array}{l}\text { Mean } \\
\text { fecundity }\end{array}$ & $\begin{array}{l}\text { Fecundity } \\
\text { range }\end{array}$ & $\begin{array}{l}\text { Num of } \\
\text { eggs/ovary gram }\end{array}$ & $\begin{array}{l}\text { Relative } \\
\text { fecundity }\end{array}$ & $\begin{array}{l}\text { Mean } \\
\text { GSI }\end{array}$ \\
\hline $7-9$ & 141 & 11.42 & 0.58 & 811 & $168-1716$ & 1398 & 71.015 & 5.05 \\
$9-11$ & 666 & 16.60 & 0.68 & 854 & $113-1555$ & 1256 & 51.45 & 4.14 \\
$11-13$ & 58 & 30.18 & 0.72 & 897 & $397-1622$ & 1246 & 29.72 & 2.46 \\
$13-15$ & 14 & 49.34 & 0.86 & 951 & $540-1484$ & 11.06 & 19.27 & 1.78 \\
$15-17$ & 2 & 69.33 & 1 & 1055 & $945-1164$ & 1055 & 15.21 & 1.24 \\
\hline Total & 881 & 17.36 & 0.67 & 857 & $113-1716$ & 1272 & 49.08 & 4.13 \\
\hline
\end{tabular}

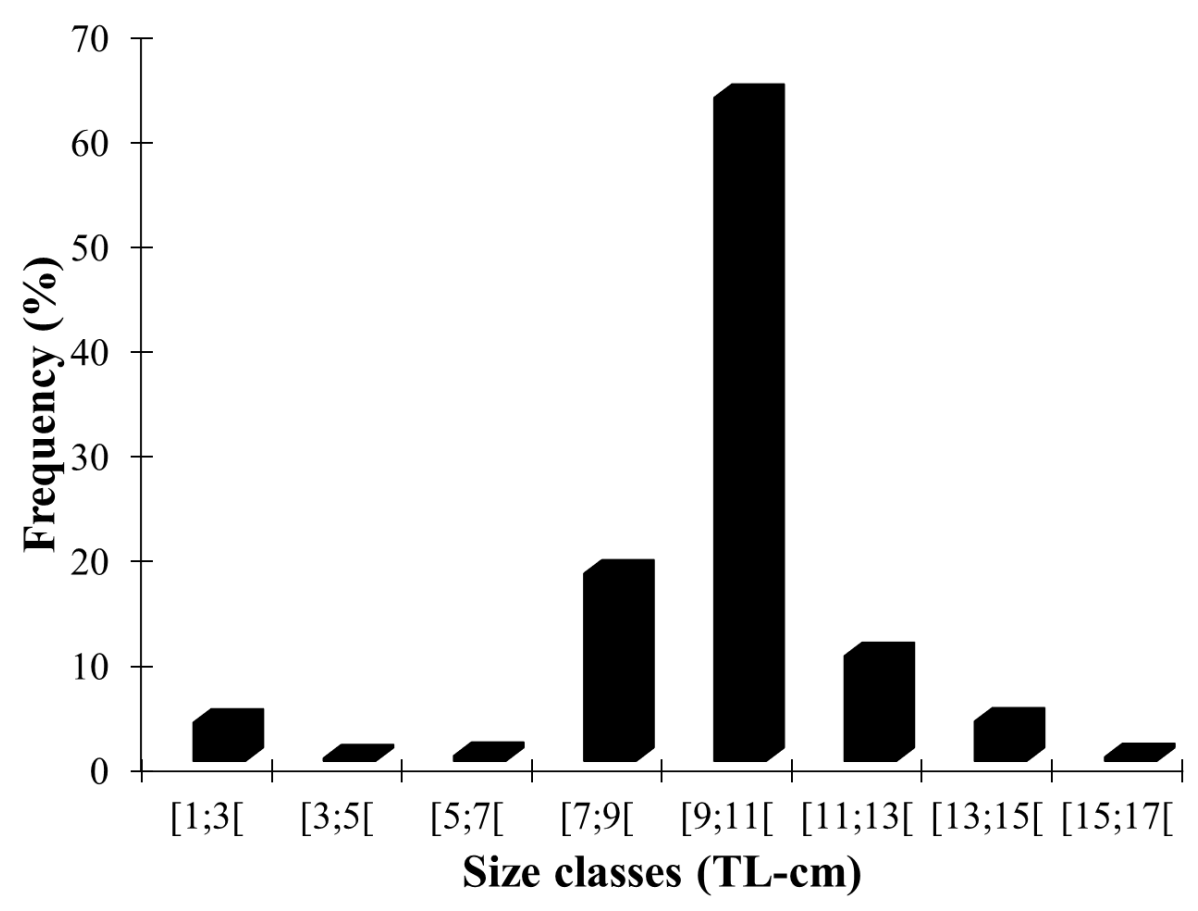

Figure 2. Size structure (TL) of H. fasciatus $(\mathrm{n}=2,818)$ collected in Okpara Stream (North-Benin) from December 2015 to Mai 2017. 


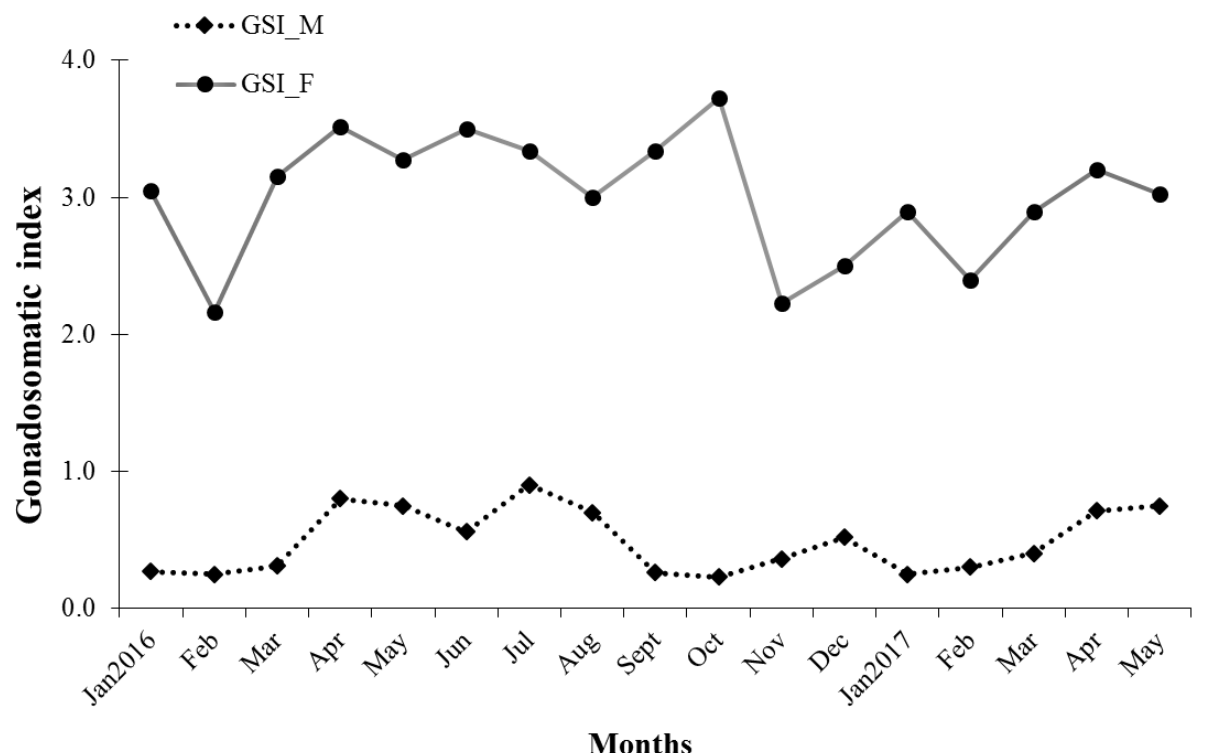

Figure 3. Variation of gonadosomatic index of H. fasciatus from December 2015 to May 2017 in Okpara stream (North Be$\operatorname{nin})$

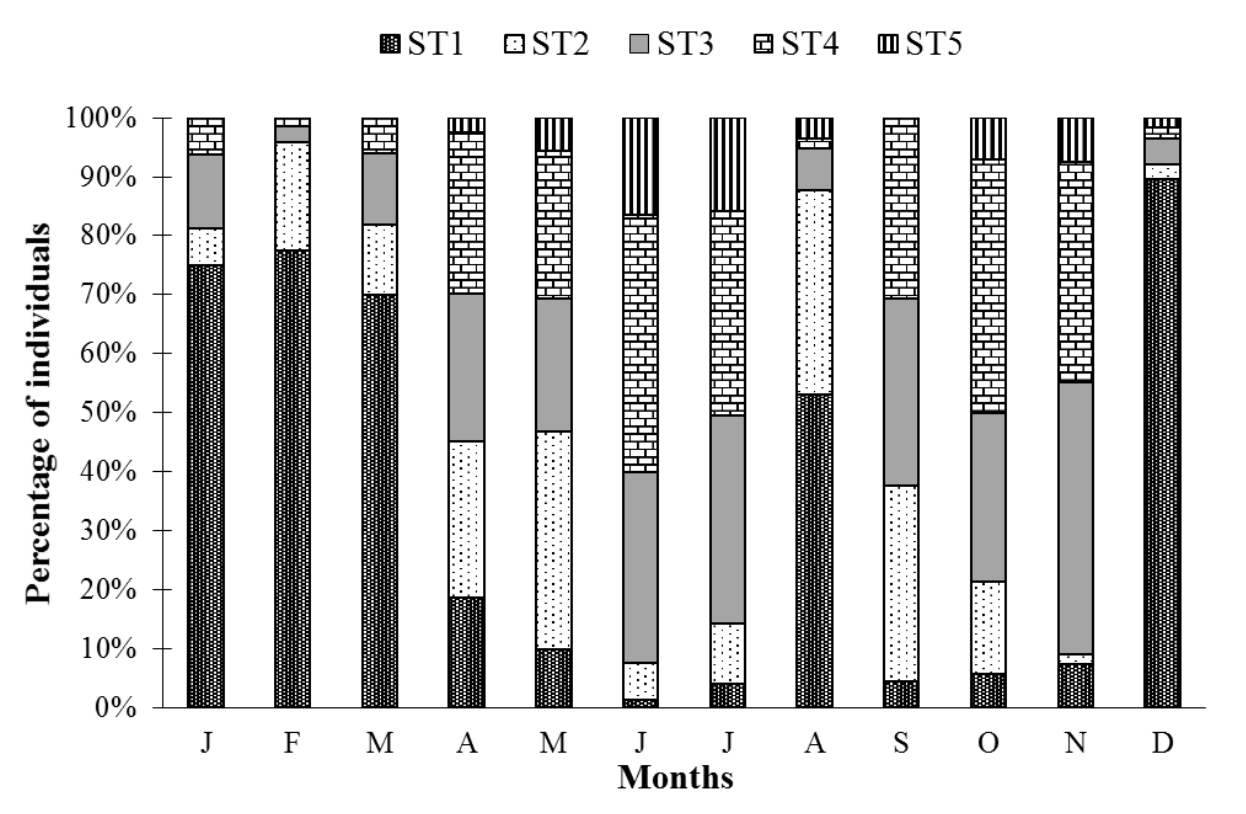

Figure 4. Percentage of gonads maturation stages in $H$. fasciatus males by months. ST1 = Immature stage; ST2 $=$ Stage of beginning of maturation; ST3 = Advanced ripening stage; ST4 = Maturation stage and ST5 = Post-spawned 


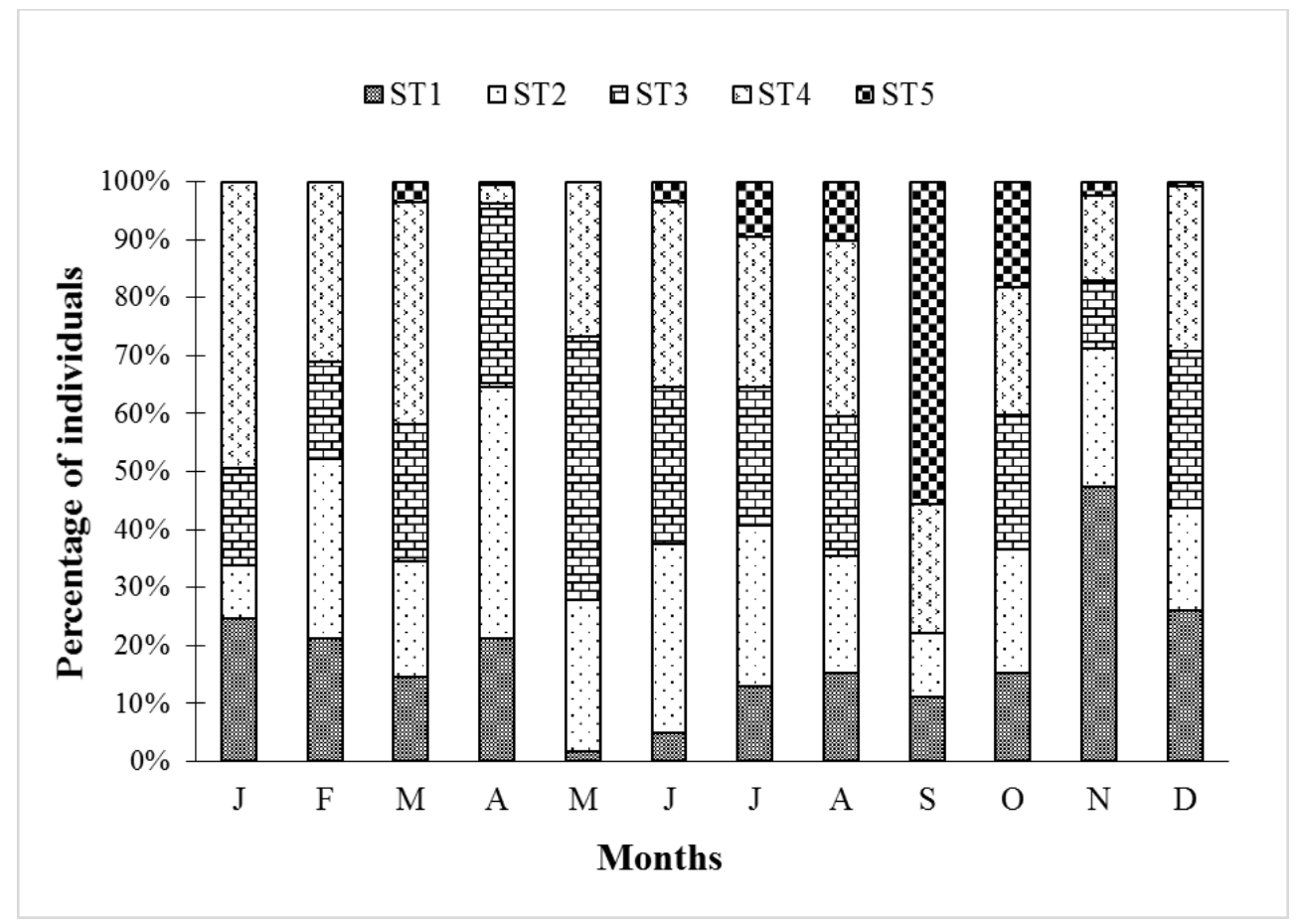

Figure 5. Percentage of gonads maturation stages in $H$. fasciatus females by months. ST1 = Immature stage; ST2 = Stage of beginning of maturation; ST3 = Advanced ripening stage; ST4 = Maturation stage and ST5 = Post-spawned

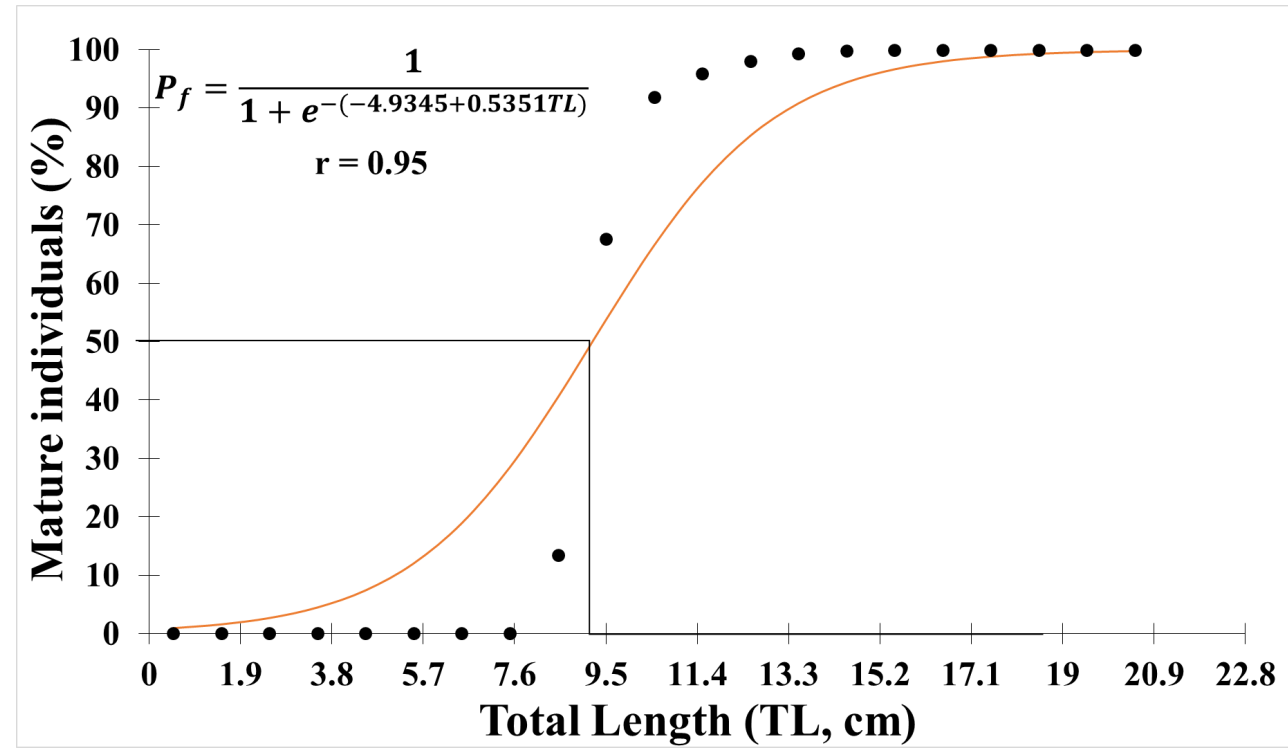

Figure 6. Lengths at first sexual maturity (L50) of $H$. fasciatus females (L50: 9.22cm, TL) from Okpara Stream, North Be$\operatorname{nin}$ 


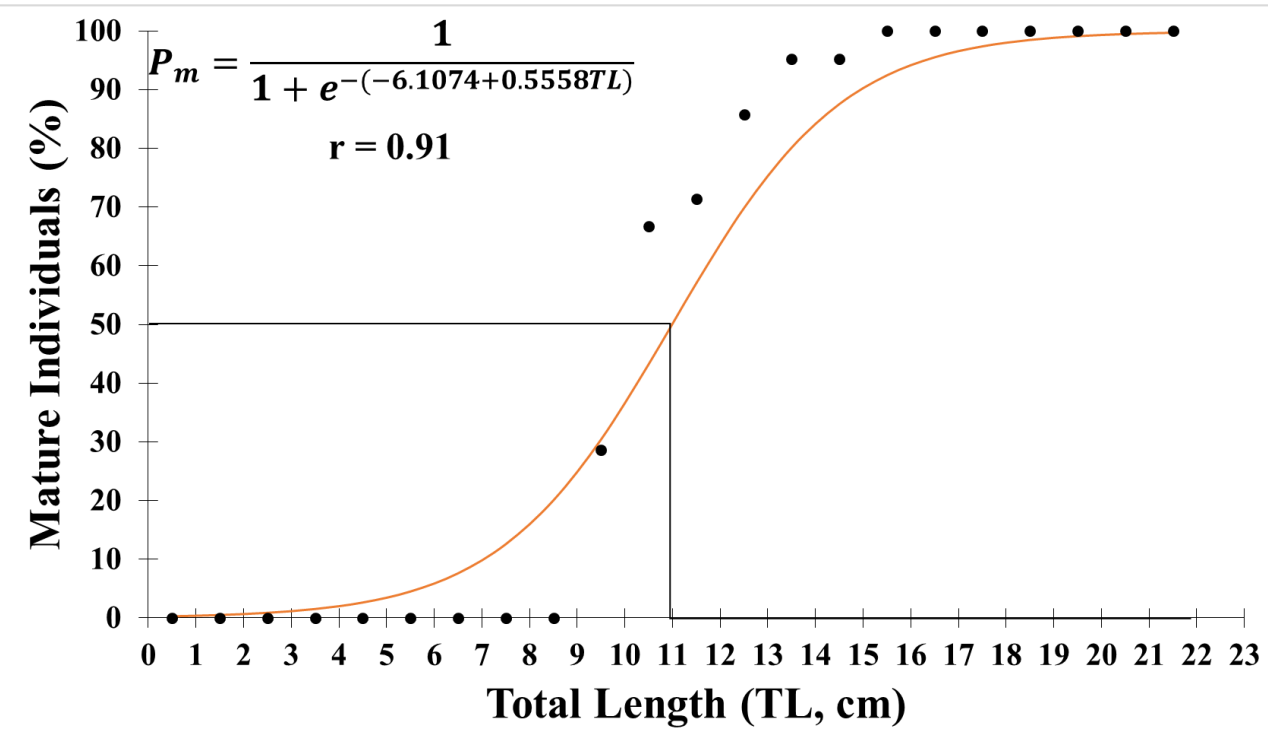

Figure 7. Lengths at first sexual maturity (L50) of H. fasciatus males (L50: $10.98 \mathrm{~cm} \mathrm{TL)} \mathrm{from} \mathrm{Okpara} \mathrm{Stream,} \mathrm{North} \mathrm{Benin}$



Figure 8. Seasonal Egg diameter frequency distribution of H. fasciatus from December 2015 to May 2017in Okpara stream, North Benin. 


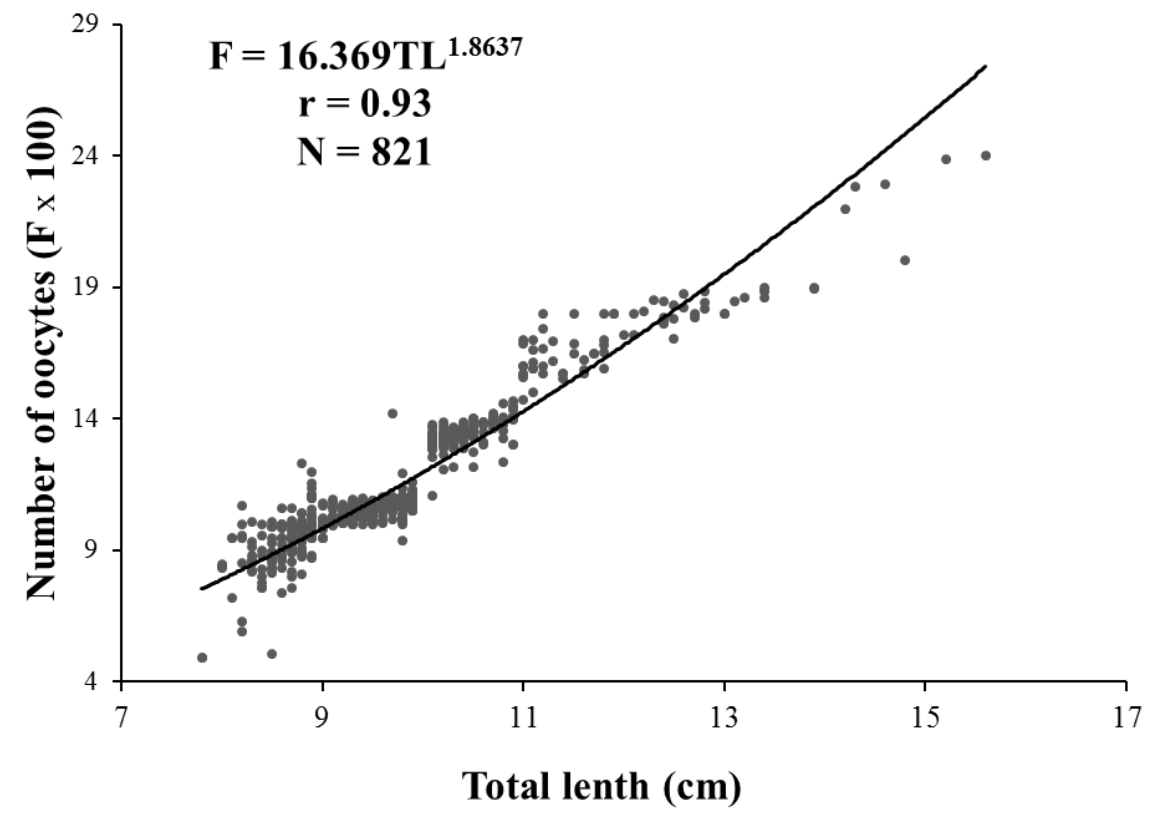

Figure 9. Relationship between Total length and fecundity of $H$. fasciatus in Okpara stream, North Benin

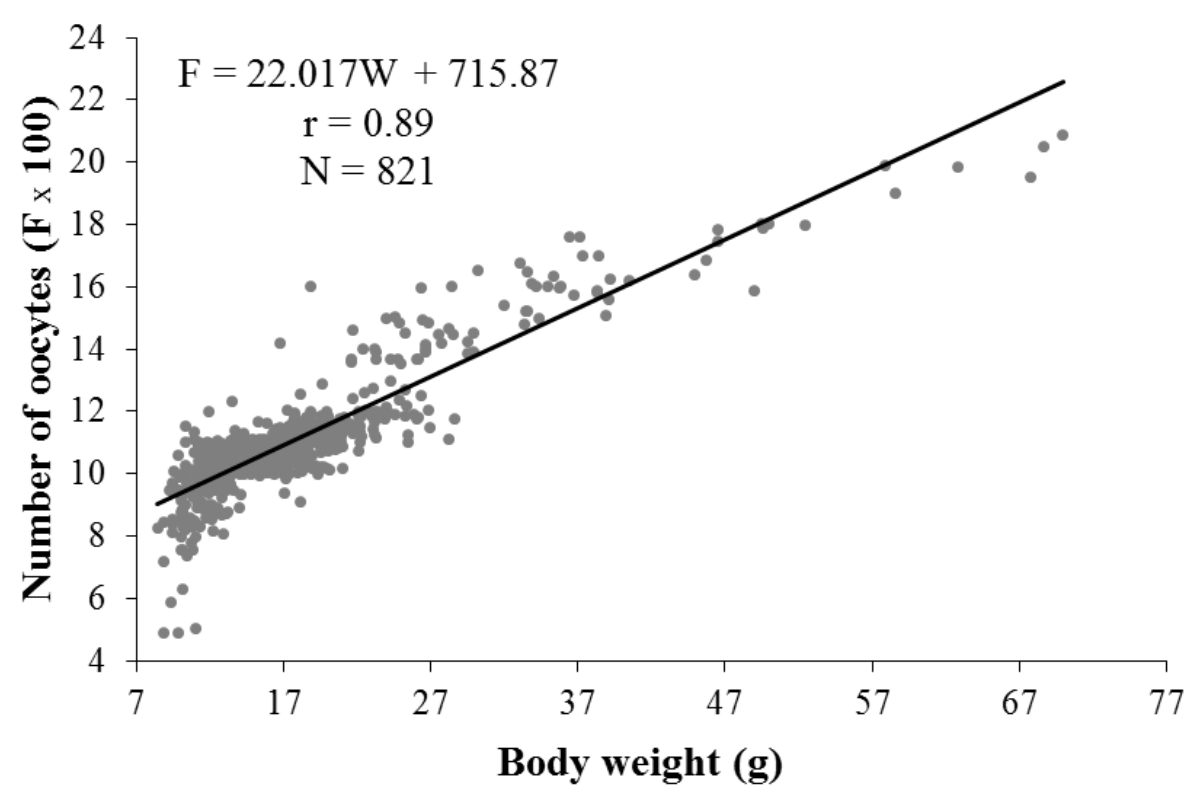

Figure 10. Relationship between Body weight and fecundity of $H$. fasciatus in Okpara stream, North Benin. 


\section{Sex-ratio, Maturation and Spawning Time}

As reported by many authors such Poulet (2004) in teleost fishes, one sex predominates over the other. This general trend agreed with that recorded for the population of $H$. fasciatus in Okpara Stream where the sex-ratio (1:1.49) recorded was in favor of females with 1 male for 1.49 female. In Owa Stream in Nigeria Olurin and Odeyemi (2010) rather reported for $H$. fasciatus population, a sex ratio 1:0.36 in favor of males. The morphological traits, the growth rates and the behavioral characteristics of males/females as selective may play in favor of one sex. Also, in general, females are more sedentary and more vulnerable to fishing gears because of parental care behavior such as egg incubation and offspring protection at the spawning grounds (Atse et al., 2009).

As reported by Sidi Imorou et al. (2019b), Okpara Stream showed favorable growth conditions for $H$. fasciatus that exhibited an isometric growth pattern (slope b: 3.0024) and a relatively high condition factor $(\mathrm{K})$ reaching 8.02 . Therefore, spawning was effective, successful and the species was perfectly established. Indeed, the current study revealed the presence of different life stages small juvenile, juvenile, sub-adult and adult in the population of $H$. fasciatus suggesting that the reproduction and the recruitment of fishes were successful (Gbaguidi and Adite, 2016). This result was also confirmed by the presence of all maturation stages in the gonads. Abundance of oocytes of big diameters $(\mathrm{d}>1.05 \mathrm{~mm})$ during the dry season $(7.29 \%)$, the wet season $(49.79 \%)$ and the flood period $(70.12 \%)$ combined with the relative abundance of ripe gonads (stage 3 and 4) indicated that in Okpara Stream, H. fasciatus breeds all seasons. This finding agreed with that reported by Albaret (1982) in Ivory Coast and by KwarfoApegyah and Ofori-Danson (2010) in Batonga Reservoir in Ghana where $H$. fasciatus spawned all year with a peak recorded in wet and flood seasons (Kwarfo-Apegyah and OforiDanson, 2010). As it is the case for many tropical fish species, the increase of water level during wet and flood seasons was the favorable condition that stimulates gonad maturation and led to spawning and recruitment (Albaret 1982; Wootton 1998; Lalèyè et al., 1995; Dadebo et al., 2003; Rutaisire and Booth 2005; Adité et al., 2006).

\section{Length at First Sexual Maturation $\left(T L_{50}\right)$}

In Okpara Stream, males of $H$. fasciatus reached their size at first maturity at a total length ( $\left.\mathrm{L}_{50}=10.98 \mathrm{~cm}-\mathrm{TL}\right)$ higher than that of females $\left(\mathrm{L}_{50}=9.22 \mathrm{~cm}-\mathrm{TL}\right)$. This sexual difference in $\mathrm{L}_{50}$, mostly tardive in males was reported for several fish species such Chrysichthys nigrodigitatus and Chrysichthys auratus (Lalèyè et al., 1995), Clarias ebriensis (Ezenwaji, 2002), Labeo horie (Dadebo et al., 2003), Labeo victorianus (Rutaisire and Booth 2005); Heterotis niloticus (Adité et al.,
2006), Clarias gariepinus, Clarias ebriensis, Schilbe intermedius, Schilbe mystus, Synodontis schall (Chikou et al., 2011), Sarotherodon galileus (Gbaguidi and Adite 2016) etc. Genetic factors including sexual dimorphism of growth and habitat conditions such as physicochemical variations and food resource availabilities could greatly affect the size at first sexual maturity (Wootton, 1998; Koné et al. 2011; Tembeni et al. 2014).

In this study, the size at first sexual maturity $\left(\mathrm{L}_{50}=9.22 \mathrm{~cm}\right.$ TL) recorded for $H$. fasciatus females agreed with that reported by Olurin and Odeyemi (2010) in Owa Stream in Nigeria and that reported by Albaret (1982) in Ivory Coast. Also, in Batonga Reservoir in Ghana, Kwarfo-Apegyah and Ofori-Danson (2010) reported similar $\mathrm{L}_{50}$ for $H$. fasciatus. In contrast, in Ogun River in Nigeria, Adebissi (1987) found a higher $\mathrm{L}_{50}=10.4 \mathrm{~cm}$-TL for $H$. fasciatus female. Though genetic traits could cause this differential $\mathrm{L}_{50}$ through breeding tactics and biological characteristics, habitat ecological status, fishery condition, population structure and environmental conditions and stockascity could together influence the length at first sexual maturity (Rutaisire and Booth, 2005). In Okpara stream, the length at first capture $\left(\mathrm{Lc}_{50}\right)$ for $\mathrm{H}$. fasciatus is $\mathrm{Lc}_{50}=8.78 \mathrm{~cm}$ (Sidi Imorou et al., 2019c). This length is lower than the length at first maturity $\left(\mathrm{L}_{50}=10.98 \mathrm{~cm}\right.$ for males and $\mathrm{L}_{50}=9.22 \mathrm{~cm}$ for females). This result suggested that in Okpara stream, specimen of $H$. fasciatus were caught before breeding for the first time. This situation could lead to a depletion of the stock of this species in the river.

Power curve fitted to total length (TL) and fecundity (F) scatter plot showed that batch fecundity significantly increase with TL $(\mathrm{r}=0.93, \mathrm{p}<0.05)$ (Figure 8). Also linear regression fitted to body weight (W) and batch fecundity scatter plot showed that fecundity significantly $(\mathrm{r}=0.89, \mathrm{p}<0.05)$ increase with body weight (Figure 9).

\section{Fecundity and Breeding Strategy}

In the current fishery survey, $H$. fasciatus showed batch fecundities ranging between 113 and 1716 oocytes (mean $=857$ oocytes) with a relative fecundity of 49.08 oocytes / g of body weight in Ivory Coast, Albaret (1982) recorded a highest fecundity that reached 2509 oocyte along with a reduced relative fecundity of 30 oocytes / $\mathrm{g}$ of body weight. In contrast, in New Bussa kigera reservoir in Nigeria, Issa et al. (2005) reported a lowest fecundity of 520 oocytes. Probably, these spatial differences in fecundities were the results of differential environmental variabilities and differential availability in food resources (Fagade et al., 1984; Issa et al., 2005). In this study, batch fecundity exhibited significant $(\mathrm{r}=0.93, \mathrm{p}<0.05)$ curvilinear relationship with total length and was positively correlated with body weight. Legendre and Ecoutin (1989) 
and Atse et al. (2009) reported similar trends in some other cichlids such as Sarotherodon melanotheron, Tilapia guineensis and Tylochromis jentinki from Ebrie Lagoon in Ivory Coast.

With regards to ovarian structure, $H$. fasciatus showed moderate oocyte diameter averaging $1.10 \pm 0.11 \mathrm{~mm}$ and varying between $0.800 \mathrm{~mm}$ and $1.5297 \mathrm{~mm}$. These diameter values were lower than those reported by Albaret (1982) in the water bodies of Ivory Coast and by Olurin and Odeyemi (2010) in Owa Stream in Nigeria where the oocyte diameters reached $1.65 \mathrm{~mm}$ and $1.94 \mathrm{~mm}$, respectively. Also, the gonads comprised oocytes at all stages of maturity regardless of month (Figures 3 and 4), suggesting that H. fasciatus displayed multiple reproduction in the Okpara River with several offspring cohorts during the same spawning season. These breeding pattern is typical to most teleost fishes and cichlids in particular (Paugy et al., 2006).

In this study, $H$. fasciatus exhibited a relative low sizes at sexual maturity $10.98 \mathrm{~cm}$-TL (males) and $9.22 \mathrm{~cm}-\mathrm{LT}$ (females), a low batch fecundity ( $\mathrm{F}=857 \pm 284.78$ oocytes), a relative low eggs diameters $(\mathrm{d}=1.10 \pm 0.11 \mathrm{~mm})$ and reproduce early. This piscivorious fish built nests in which eggs are laid and had multiple layers and practices parental care for the survival of its offspring (Stiassny et al., 2007). These biological characteristics indicate that $H$. fasciatus has a demographic strategy between selections " $\mathrm{r}$ " and "K" but much closer to selection " $r$ ". This strategy optimizes the survival of eggs, larvae and juveniles through the practice of parental care with moderately early maturation associated with several spawnings throughout the year (Winemiller and Rose, 1992).

\section{Conclusion}

The current study on the reproductive biology of $H$. fasciatus gives valuable information on the spawning time, fecundity and spawning strategy of this fish species in Okpara stream. The favorable environmental conditions of Okpara stream coupled with the all seasons breeding and the spawning strategy characterized by the high offspring survivorship (parental care), the high accounted for the prominence in this ecosystem. However, values of size at first sexual maturity for both sexes superior to the length at first capture require special attention in the sustainable management plan for this ecosystem.

\section{Compliance with Ethical Standard}

Conflict of interests: The authors declare that for this article they have no actual, potential or perceived conflict of interests.

Ethics committee approval: This study was conducted in accordance with ethics committee procedures of animal experiments.
Funding: This research was funded by the "Laboratory of Ecology and Management of Aquatic Ecosystems" and by the authors.

Acknowledgments: We are grateful to the "Laboratoire d'Ecologie et de Management des Ecosystèmes Aquatiques, Département de Zoologie, Faculté des Sciences et techniques, Université d'Abomey-Calavi" for providing us logistic assistances. We are also grateful to Okpara's fishermen for their help during the investigation. We express our gratitude to Amoussouga Illary and Mitobaba Aurel for their assistance in laboratory works.

\section{References}

Adite, A., Winemiller, K.O., Fiogbe, E.D. (2006). Population structure and reproduction of the African bonytongue Heterotis niloticus in the So^ River-floodplain system (West Africa): implications for management. Ecology of Freshwater Fishes, 15, 30-39.

https://doi.org/10.1111/j.1600-0633.2005.00119.x

Albaret, J.J. (1982). Reproduction et fécondité des poissons d'eau douce de Côte-d'Ivoire. Revue Hydrobiologique Tropicale, 15, 347-371.

Adite, A., Gbaguidi, H.M.G.A., Ategbo, J-M. (2017). Reproductive biology and life history patterns of the Claroteid, Chrysichthys nigrodigitatus (Lacépède: 1803) from a Manmade lake in Southern Benin. Journal of Fisheries and Aquatic Science, 12, 106-116.

https://doi.org/10.3923/jfas.2017.106.116

Chikou, A., Laleye, P.A., Bonou, C.A., Vandewalle, P., Philippart, J-C. (2011). Tailles de première maturité et de capture de six espèces de poisson-chat dans le delta de l'Ouémé au Bénin (Afrique de l'Ouest). International Journal of Biological and Chemicale Science, 5(4), 1527-1537. https://doi.org/10.4314/ijbcs.v5i4.18

Atse, B.C., Konan, K.J., Kouassi, N.J. (2009). Biologie de la reproduction du Cichlidae Tylochromis jentinki dans la lagune Ebrié (Cote d'Ivoire). Cymbium, 33(1), 11-19.

Dadebo, E., Ahlgren, G., Ahlgren, I. (2003). Aspect of reproductive biology of Labeo horie Heckel (Pisces: Cyprinidae) in Lake Chamo. Ethiopia. African Journal of Ecology, 41, 31-38.

https://doi.org/10.1046/j.1365-2028.2003.00404.x 
Daget, J. (1956). La pêche à Diafarabé. Études monographiques. Bulletin de l'Institut fondamentale de l'Afrique noire, série $B, 18(1-2), 97$.

Dossou-Yovo, E. (2009). Modélisation du fonctionnement hydrologique dans le bassin versant de l'Okpara à l'exutoire de Kaboua dans un contexte de changement global: contribution à la gestion intégrée des ressources en eau. Thèse d'Ingénieur Agronome, Faculté des Sciences Agronomiques, Abomey-Calavi, Bénin. 106p.

Ezenwaji H.M.G. (2002). The biology of Clarias ebriensis Pellegrin, 1920 (Osteichthyes: Clariidae) in an Africa rainforest river basin. Fisheries Research, 54, 235-252.

https://doi.org/10.1016/S0165-7836(00)00291-5

Fagade, S.O., Adebisi, A.A., Atanda, A.N. (1984). The breeding cycle of Sarotherodon galilaeus in the IITA Lake, Ibadan, Nigeria. Archives Hydrobiologia, 100(4), 493 - 500.

Gbaguidi, H.M.G.A., Adite, A. (2016). Reproductive ecology and establishment of naturally colonized tilapine Cichlid, Sarotherodon galilaeus (Pisces: Actinopterigii: Perciformes) from a man-made lake, Southern Benin, West Africa: implications for sustainable fisheries and aquacultural valorization. International Journal of Fisheries and Aquatic Studies, 4(3), 278-287.

Ghorbel, M., Jarboui, O., Bradai, M.N., Bouain, A. (1996). Détermination de la taille de première maturité sexuelle par une fonction logistique chez Limanda limanda, Pagellus erythrinus et Scorpaena porcus. Bulletin INSTM, 3, 2427.

Issa, E.A., Olufeagba, S.O., Raji, A. (2005). Effects of some environmental factors on the fecundity of Tilapia species (Family: Cichlidae) in Kigera Reservoir, New Bussa. 19th Annual Conference of the Fisheries Society of Nigeria (FISON), 29th Nov. - 03 Dec. 2004, Ilorin, Nigeria.

Jackson, A.T., Adite, A., Roach, K.A., Winemiller, K.O. (2013). Fish assemblages of an African river floodplain: a test of alternative models of community structure. Ecology of Freshwater Fish, 22, 295-306.

https://doi.org/10.1111/eff.12026
Kantoussan, J. (2007). Impact de la pression de pêche sur l'organisation des peuplements de poissons: application aux retenues artificielles de Selingue et de Manantali, Mali, Afrique de l'Ouest. Thèse de doctorat, Agrocampus, Rennes, $195 p$.

Koné, N., Berte, S., Kraidy, A.L.B., Kouamelan, E.P., Koné, T. (2011). Biologie de la reproduction du Clupeidae Pellonula leonensis Boulenger, 1916 dans le lac de barrage de Kossou (Côte d'Ivoire). Journal of Applied Biosciences, 41, 2797-2807.

Kora, O. (2006). Monographie de la commune de Parakou. Cabinet « Afrique Conseil », 44p.

Kuela, J.M.D. (2002). Étude des peuplements ichtyologiques de la Comoé et des modes d'exploitation piscicole dans la zone agro-sylvo-pastorale du projet GEPRENAF. Mémoire de fin d'étude, Université polytechnique de Bobo Dioulasso, $73 \mathrm{p}$.

Kwarfo-Apegyah, K., Ofori-Danson, P.K. (2010). Spawning and recruitment patterns of major fish species in Bontanga reservoir, Ghana, West Africa. Lakes \& Reservoirs: Research and Management, 15, 3-14.

https://doi.org/10.1111/j.1440-1770.2010.00418.x

Lalèyè, P., Chikou, A., Philippart, J-C., Teugels, G., Vandewalle, P. (2004). Étude de la diversité ichtyologique du bassin du fleuve Ouémé au Bénin (Afrique de l'Ouest). Cybium, 28(4), 329-339.

Lalèyè, P., Phillipart, J-C., Poncin, P. (1995). Biologie de la reproduction de deux espèces de Chrysichthys (Siluriformes, Bagridae) du lac Nokoué et de la lagune de Porto Novo au Bénin. Journal of African Zoology, 109(3), 213224.

Legendre, M., Ecoutin, J.M. (1989). Suitability of brackish water tilapia species from the Ivory Coast for lagoon aquaculture: Reproduction. Aquatic Living Resources, 2, 71-79. https://doi.org/10.1051/alr:1989009

Lévêque, C., Paugy, D. (2006). Les poissons des eaux continentales africaines: Diversité, écologie, utilisation par l'homme. IRD Editions. 573p. 
Stiassny, M.L.J., Teugels, G.G., Hopkins C.D. (éd.) (2007). Poissons d'eaux douces et saumâtres de basse Guinée, ouest de l'Afrique centrale, Collection Faune et Flore tropicales. IRD, Publications scientifiques du Muséum, MRAC, ISSN: 1286-4994

Montchowui, E., Niyonkuru, C., Ahouansou Montcho, S., Chikou, A., Lalèyè, P. (2007). L'ichtyofaune de la rivière Hlan au Bénin (Afrique de l'Ouest). Cybium, 31(2), 163-166. https://doi.org/10.4314/ijbcs.v2i2.39733

Murphy, B.R., Willis, D.W. (1996). Fisheries Techniques. Second edition. American Fisheries Society, Bethesa, Maryland. ISBN-13: 978-1888569001

Olurin, K.B., Odeyemi, O.I. (2010). The reproductive biology of the fishes of Owa Stream, South-West Nigeria. Research Journal of Fisheries and Hydrobiology, 5(2), 81-84.

Paugy, D., Lévêque, C., Teugels, G.G. (2003). Faune des poissons d'eaux douces et saumatres de l'Afrique de l'Ouest. Tome 1. IRD Editions, MNHN, Paris, France \& MRAC, Tervuren, Belgique, $457 \mathrm{p}$.

Paugy, D., Lévêque, C., Duponchelle, F. (2006). La reproduction in Lévêque C., Paugy D. (2006). Les poissons des eaux continentales africaines : Diversité, écologie, utilisation par l'homme; IRD Editions, Paris, France, ISBN 2e édition : 2-7099-1589-8

Poulet, N. (2004). Le sandre (Sander lucioperca L.) : Biologie, comportement et dynamique des populations en Carmargue (Bouches du Rhône, France). Thèse de Doctorat, Université de Toulouse III, France, 300 p.

Rutaisire, J., Booth, A.J. (2005). Reproductive biology of ningu, Labeo victorianus (Pisces: Cyprinidae), in the Kagera and Sio Rivers, Uganda. Environmental Biology of Fish, 73, $153-162$

https://doi.org/10.1007/s10641-004-5564-8
Sidi Imorou, R., Adite, A., Arame, H., Chikou, A., Adjibade, N.K., Sonon, P.S. (2019a). Ichthyofauna of Okpara Stream, a Tributary of Oueme River, Benin, West-Africa. International Journal of Sciences, 8(5), 53-66.

https://doi.org/10.18483/ijSci.2052

Sidi Imorou, R., Adite, A., Sossoukpe, E., Abou, Y. (2019b). Length-weight models and condition factors of fishes from Okpara Stream, Oueme River, Northern-Benin. International Journal of Forest, Animal and Fisheries Research, 3(3), 65-80.

https://doi.org/10.22161/ijfaf.3.3.1

Sidi Imorou, R., Adite, A., Sossoukpe, E., Adjibade, N.K., Arame, H., Sonon, SP. (2019c). Demographic parameters and exploitation rate of five key fishes of Okpara Stream, Oueme River, Benin, West Africa. International Journal of Aquatic Biology, 7(6), 332-341.

https://doi.org/10.22034/ijab.v7i6.642

Tembeni, J.M., Micha, J.C., Mbomba, B.N.S., Vandewalle, P., Mbadu, V.Z. (2014). Biologie de la reproduction d'un poisson chat Africain Euchilichthys guentheri (Schilthuis, 1891) (Mochokidae, Siluriformes) au Pool Malebo, Fleuve Congo (République Démocratique du Congo). Tropicultura, 32(3), 129-137.

Winemiller, K.O., Rose, K.A. (1992). Patterns of life-history diversification in North American fishes: implications for population regulation. Canadian Journal of Fisheries and Aquatic Science, 49, 2196-2218.

https://doi.org/10.1139/f92-242

Winemiller, K.O. (1992). Fish assemblages across a complex, tropical freshwater/marine ecotone. Environmental Biology of Fishes, 3, 29-50.

https://doi.org/10.1007/BF00004783

Wootton, R.J. (1998). Ecology of Teleost Fishes. Kluwer Academic Publishers [Fish and Fisheries Series, no. 24], Dordrecht, The Netherlands. ISBN: 978-0-412-84590-1 